\title{
The role of cooperative learning in the introductory stages of art teacher training programmes in Japan
}

\author{
Toshio Naoe University of Tsukuba, Japan
}

\begin{abstract}
In this article the outcomes and issues of cooperative learning in teacher training programmes for undergraduate art students are examined. Cooperative learning utilizes human interaction in small groups in pursuit of shared goals. The author designed and delivered two introductory courses at the University of Tsukuba that were added to the teacher training programme as a result of the reform to the Japanese national teacher education system in 2000. The courses, which were informed by principles and methods of cooperative learning, had a positive impact on student engagement and satisfaction. Although the study workload is heavier since these reforms were put into place there has been a steady increase in numbers of art students entering and finishing teacher training.

\section{要約}

本論文では美術の学士課程学生のための教職課程における協同学習の成果と課題を検討する。協 同学習は少人数グループによる参加者間の相互作用を活用して共通の目標を目指すものである。 筆者は2000年の日本の教員養成制度改革の結果教職課程に追加された二つの導入的科目を筑波大 学で担当している。協同学習の原則と方法によって指導された本事例では、学生の積極的な取り 組みと満足度が見られる。国の教員養成改革のもとでもたらされた新科目による学習量の増加に もかかわらず、本事例では教職課程の履修開始と修了の学生数が堅実に増加した。
\end{abstract}

\section{Keywords}

Cooperative learning, secondary teacher education, art, curriculum development, Japan

\section{Aims and background}

The purpose of this paper is to assess the utility of cooperative learning in teacher training programmes for undergraduate art students. Cooperative learning utilises human interaction in small groups in pursuit of shared goals. This study describes and evaluates two introductory courses delivered at the University of Tsukuba in 2003 designed and implemented by the author. The evaluation draws on a variety of data including student work, statistical data pertaining to student 
performance, and the results of a confidential survey of student engagement and satisfaction.

As is the case in many contemporary societies, education in Japan is subject to much public criticism and scrutiny. Consequently, each government administration introduces new teacher education reforms. From 1997 to 1999, the Teacher Education Advisory Panel submitted proposals to the Japanese government for enhancing teacher qualifications and training that emphasised global perspectives alongside maintaining teacher standards in a society undergoing continuous change. As Takakura (2000) has pointed out, educational reformers today have to take global change such as the information explosion and environmental destruction into account. In Japan they must also consider domestic changes such as the declining birth rate and rapid population ageing together with serious problems occurring in Japanese schools, like bullying, violence, truancy and classroom disruption. Given the speed and scale of change occurring globally, domestically and within schools, the panel proposed approximately thirty-four new teacher competencies. Their recommendations for teacher education reform were realised in the form of an amendment to the Teacher Licensing Act of 2000 that regulates licenses for primary and secondary school teachers, and authorises university teacher education programmes.

The most direct impact on university provision for teacher education was on pedagogy and teaching practice. Universities were required to offer two new courses; "The Teaching Profession" and "Comprehensive Seminars". In the former, students learn about their educational roles and responsibilities and reflect on their own aptitudes for teaching. In the latter they design and implement curriculum projects that respond to global, national, and local community perspectives. The development of specific course content is left to the discretion of each university.

Because these changes have increased the student teacher workload I was concerned they might withdraw from teacher training. I have been employed at the School of Art and Design at the University of Tsukuba since 2000, teaching an optional undergraduate training programme for secondary art teachers. Historically, art students have shown little interest in entering the teaching profession, and this has had negative consequences for curriculum development. A questionnaire survey of art students beginning teacher training I conducted in April 2003 showed that the significance they attached to the profession and their motivation to teach was very low (See Table 1). In response to these adverse conditions, I introduced principles of cooperative learning into the programme. 


\begin{tabular}{lcc}
\hline \multicolumn{1}{c}{ items } & number of respondents & percentage \\
\hline firm intention to become a teacher & 5 & 5.7 \\
give priority to teaching profession & 10 & 11.5 \\
one of my career choices & 45 & 51.7 \\
never want to become a teacher & 24 & 27.6 \\
uncertain & 3 & 3.4 \\
\hline total & 87 & 100.0 \\
\hline
\end{tabular}

Table 1: Art student teachers' views on teaching as a future career

\section{History of cooperative learning in Japan}

Some primary and secondary schools in Japan use cooperative learning (in a broad sense) as an alternative educational approach to the typical teacher-centered approach using a competitive system of evaluation. "Buzz learning," a Japanese term, which has been a practical study on group dynamics in schools since the 1960's, was one of the common strategies applied in the cooperative approach (Shiota, 1989). (The word buzz refers to the sound of learner voices during group discussion.) According to Sugie (2001), the basis of cooperative learning is good human relations supported by trust: teachers act as facilitators, provide well-planned curricula syllabus, engage in formative evaluation and consistently promote collaborative group work. A Western researcher (Mason, 1994) has commented that "love-centred pupil-teacher interaction" is evident in Japanese classrooms. As a cooperative learning strategy, "buzz" learning appears to be influenced by a specifically Japanese emphasis on valuing close human relationships.

Beginning in the late 1970s, cooperative learning declined in Japan as a result of a trend towards individualism (Sugie, 2004). Beginning in the late 1990s, however some educators began to pay attention to the possibility of revisiting cooperative learning strategies again, probably because there was widespread criticism of the competitive culture prevailing in the education system, and of a desire to reverse a perceived decline in social interaction in contemporary life.

Universities are placing more emphasis on improving education at the present time because they have to compete for a limited pool of customers in the context of population decline. The Japanese government is trying to raise teaching standards in higher education also and has made it obligatory for each university to organise continuing staff development (so-called "faculty development") (University Establishment Standards 1956/2007). University staff concerned about student learning have taken advantage of these initiatives to improve their own teaching, and some of them are experimenting with cooperative learning.

\section{Research into cooperative learning in higher education}


Sekita (2004) has described and analysed three cases of cooperative learning in higher education courses in Japan. They include: i) an economics course in which student motivation was maintained by combining lectures with informal group work; ii) a foreign language course in which a learnerfriendly environment was fostered using a system of peer review in marking oral tests, and iii) a physical education course in which student attendance improved after team members shared common goals.

The benefits of cooperative learning at university level were demonstrated also when a new curriculum for freshman was introduced in Kurume University in Japan with the objective of improving their basic learning skills (Yasunaga, Ishikawa, Mitsuzono, 2006). This study reported remarkable improvement in student attendance on campus, and pointed out that there was a correlation between the degrees of successful discussion in class and student satisfaction. The success of the new curriculum varied among the forty classes involved with different teachers. This suggests that active commitment of teachers based on a good understanding of the principles of cooperative learning is a necessary condition.

\section{Potential of cooperative learning for pre-service art teacher training}

In May 2003, I used the results of a self evaluation exercise to investigate the potential of cooperative learning to enhance art students' teaching competencies on an introductory course in teacher training at the School of Art and Design, University of Tsukuba. I created a self-evaluation sheet based on the list of thirty-four teaching competencies proposed by the Advisory Panel in their report to government (1997). Students assessed their own competencies as 'good', 'moderate', or 'difficult' for each item on the list, and were required to provide personal evidence for these judgments. Table 2 shows the results. Items included this table were sorted according to 'scores'; i.e. differences between numbers of respondents indicating 'good' and 'difficult' in each item. For example, the score of the first ranking item is forty-three, which is forty-seven (good) minus four (difficult). If this 'good minus difficult' score is higher, more students are confident on their competency about that item. The scores are intended to be a rough indicator only of the students' self-evaluations of their own teaching competences. 


\begin{tabular}{|c|c|c|c|c|c|}
\hline \multirow[b]{2}{*}{ rank } & \multirow{2}{*}{$\begin{array}{l}\text { Teaching competencies as stated in Advisory Panel Report (1997) (ranked from } \\
\text { highest to lowest score) }\end{array}$} & \multicolumn{3}{|c|}{ number of respondents } & \multirow{2}{*}{$\begin{array}{l}\text { score } \\
\text { good-difficult }\end{array}$} \\
\hline & & good & moderate & difficult & \\
\hline & 1Ability to pursue continuous self-education & 47 & 27 & 4 & 43 \\
\hline & 2Individualism & 43 & 32 & 3 & 40 \\
\hline & 3Respect for different views and values & 43 & 31 & 4 & 39 \\
\hline & There are 34 items altogether, but no. 4 to no. 26 are omitted in this table. & - & - & - & - \\
\hline & 27Ability of human interaction & 16 & 45 & 17 & -1 \\
\hline & 28Respect for contributions to the international community & 17 & 37 & 24 & -7 \\
\hline & 29Ability to apply knowledge in practice & 15 & 40 & 23 & -8 \\
\hline & 30 Understanding role of education in society & 13 & 33 & 32 & -19 \\
\hline & 31Communication skills & 11 & 36 & 31 & -20 \\
\hline & 32Media literacy & 12 & 33 & 33 & -21 \\
\hline & 33Basic computer literacy & 16 & 19 & 43 & -27 \\
\hline & 34Ability to communicate in foreign languages & 6 & 20 & 52 & -46 \\
\hline
\end{tabular}

Table 2: Student self-evaluations of teaching competences

It is clear from the results shown in Table 2, that the students generally had positive views of their personal development (continuous self-education, individualism, and respect for different points of view). On the other hand, they tended to lack confidence in the areas of communication skills, media and computer literacy. "Affinity with individualism" and " lacking confidence in social communication skills" were recurring tendencies. Although we do not know if this applies to all art students in Japan, the findings have implications for the way I consider and design art teacher education programmes.

Cooperative learning does not simply entail organising group work. According to Sekita (2004) each group member has to share a common goal and it requires 'positive interdependence'. This means instructors have to design and maintain learning environments in which each individual's advancement in the learning process simultaneously contributes to the learning of other group members. It is frequently contrasted with competitive and individual learning; in the former individual learners participate in a race and compete with each other and, in the latter a personal goal is identified for each one (Johnson et al. 1991/2001, p. 26).

Cooperative learning aims to advance learners' abilities through the formation of a positive interdependent community. The new teacher training courses in the School of Art and Design, University of Tsukuba follow specifications outlined in the Advisory Panel Report, and also have two main objectives and/or orientations: i) investigating the effects of cooperative learning on teacher education programmes, and ii) developing student teachers' cooperation skills.

\section{Step 1: The Teaching Profession}

At the University of Tsukuba, a course called 'Teaching Profession', is offered to freshmen over a period of approximately six months in their first two terms. As the first course in the teachertraining programme, sessions are designed to encourage consideration of teaching through a range 
of workshop-type activities that emphasise cooperation gradually. Table 3 shows a typical sequence of topics and the way cooperation is introduced.

\begin{tabular}{ll}
\hline Topics & Cooperation \\
\hline Guidance on teacher training programme & individual \\
Listening to the other: discovering teaching competencies & peer interview, informal group \\
Teaching profession as depicted in films & individual \\
Talking to your future students & presentation, informal group \\
Reflection on teaching competencies & individual \\
Teaching profession as depicted in films 2 & short discussion, informal group \\
Guide to practice-teaching in schools & short discussion, informal group \\
Reading about education in news media: media study & short discussion, informal group \\
Guide to recruiting tests for teaching & short discussion, informal group \\
How to search for a job in education & short discussion, informal group \\
\hline
\end{tabular}

\section{Table 3: Teaching Profession: Topics and use of cooperation}

The first encounter with cooperative-type learning occurs in the second session called "Listening to the other: discovering teaching competencies". This workshop involves peer interviews and is intended to foster the attitudes of acceptance that are one of the most essential teacher competencies. Students form into pairs by lot, and proceed to interview each other using different types of questions ranging from "collect as many pieces of information as possible about your partner in seven minutes", to more personal ones such as "find out three future plans your partner has in five minutes". After the interviews, they are asked to identify three teaching competencies partners already posses and communicate their findings. This exercise employs the cooperative learning strategies of informal group work combined with an interdependent task. It is intended to develop the student teachers' ability to create an accepting atmosphere and increase awareness of individual's personal qualities.

At first, some students are reluctant to talk to each other, but the game-like ethos soon leads to active engagement and the classroom becomes filled with buzzing voices. At the end of the exercise, many express surprise they have communicated so much to people they do not know in such a short time. This session functions as an introduction to learning behaviour in a cooperative environment.

In the latter half of the course, every session is accompanied by short discussions in informal groups (a provisional group of two to four students). This type of group work is often used in cooperative learning, the main aim being to ensure students' understanding of the lesson content. It is typically conducted over a succession of short sessions of around five to seven minutes and 
based on discussion and/or a task designed to advance and deepen levels of comprehension and cooperation (Johnson et al., 2001).

The number of students who completed the Teaching Profession Course at the School of Art and Design in the University of Tsukuba increased from 58 in 2000 to 82 in 2003. This increase represents nearly 80 per cent of all freshmen in the School of Art and Design, and the level has been maintained since 2003. In other words, the school has been successful in attracting a more diverse range of art students into teacher training. Their positive engagement, especially in the latter half of the course, is proof that the methods and principles of cooperative learning are playing a key role in creating a human learning environment and generating art student motivation for teaching. This is especially true at the very outset of the course, where the effective use of informal group work clearly functions to decrease student resistance to cooperative learning.

\section{Step 2: Comprehensive Seminar}

The Comprehensive Seminar is divided into two parts focusing on "analysing and investigating problems" and "developing teaching programmes and materials". Each part lasts one term, or three months, and students propose and design educational projects in formal groups In cooperative learning, 'formal grouping' is used for long-term projects that continue throughout a course. The students seem to experience a deeper sense of community and accomplishment this way and it facilitates conflict resolution.

The students' main task in this seminar is to investigate and evaluate the use of museums as learning environments and propose improvements. The objective is i) to foster student awareness of the role of arts in society, ii) to develop their abilities for the use of cultural resources in local communities, and iii) to develop their abilities for networking among people. The approach taken to is not dissimilar to the American initiatives in educational art criticism in the 1970 s that sought to empower students to become the central players in interpreting and judging works of art The following quotation from the book by Edmund Feldman is used in the Comprehensive Seminar to encourage student teachers to propose a stimulating plan for an educational exhibition. Although it refers to a museum tour, the central principle can be applied to designing other kinds of viewer experience;

The appropriate role of a teacher or museum docent is to design a strategy of commentary and questioning that will stimulate descriptive, analytic, and interpretive operations by the viewers. Otherwise, the guided museum tour is like visiting a restaurant where someone else dines on the food and tells you how good it is. (Feldman, 1970, p.358)

In Seminar 1, groups of three students visit several art exhibitions in the Tokyo area. They evaluate 
them from the perspectives of schoolteachers and learners, and then write proposals for how to improve them so they support and enhance children's learning. In a group meeting organised after the visit, problems in existing learning environments are identified and shared. A brainstorming session is used to build accepting relationships among members at an early stage of this group work while they investigate possible solutions.

At the end of Seminar 1, groups are matched against each another for the purposes of presenting proposals and peer evaluation. The process is supervised by the instructor using formal group interviews and occasional consultation. The content of the proposals and levels of cooperation are monitored. Group work is followed by an individual written assignment in which students reflect on the task and each group members' contribution (Table 4).

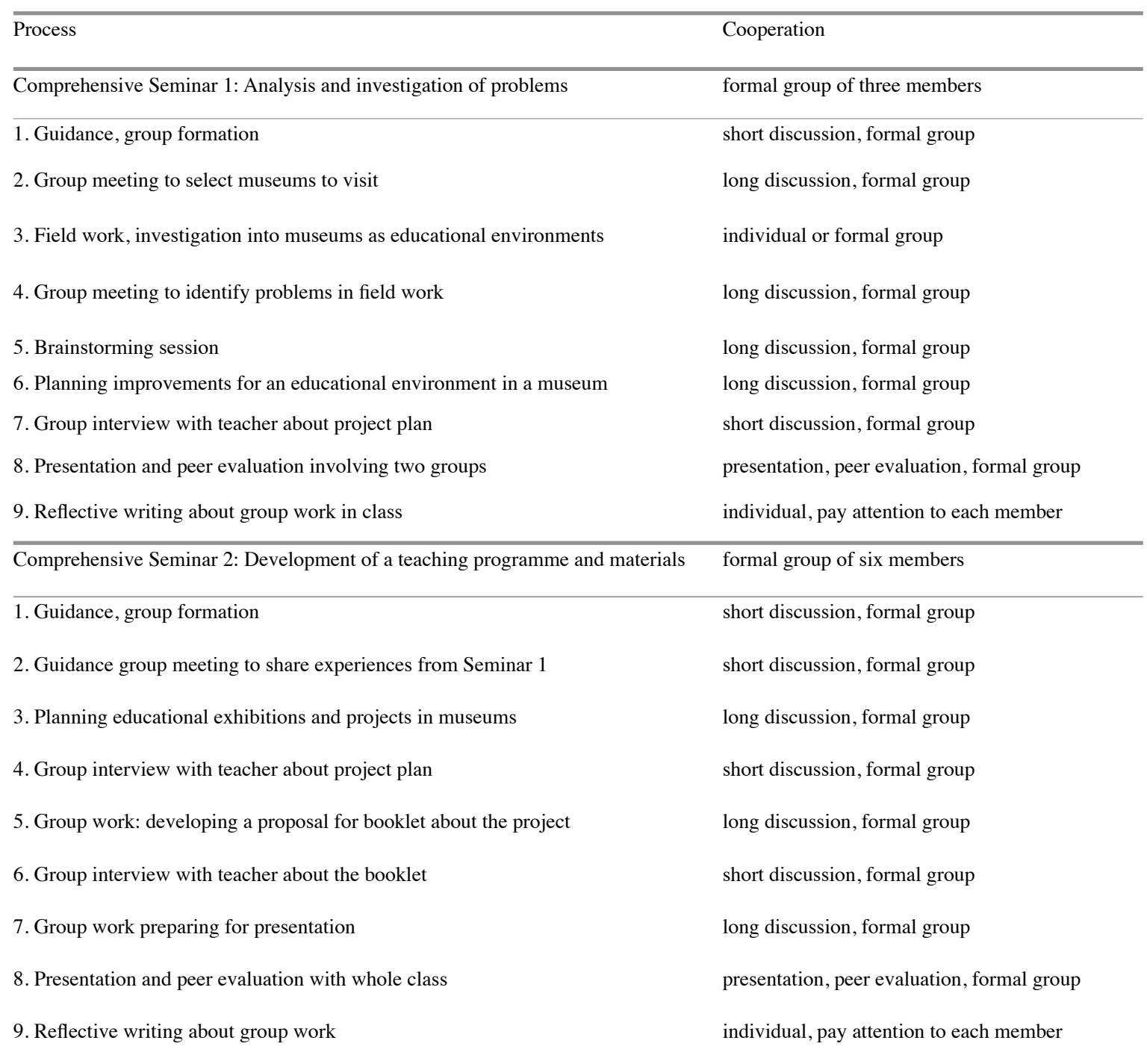

\section{Table 4: Use of cooperation in Comprehensive Seminars}

In Seminar 2, students work in larger groups of six members. They are encouraged to select 
members from various fields. Each group is given a resource pack containing examples of viewercentred exhibitions and museum activities, together with information about a local museum collection and gallery space. Students are encouraged to propose a "dream plan" for an art exhibition and educational project. Sometimes, their plans are unrealistic and they fail to consider practical concerns. However, a spirit of amateurism is permitted and they are encouraged to challenge conventional ideas from the perspective of "art for education and people" and "not for curators'.

\section{Elements of cooperative learning}

According to Johnson (2001) and Sekita (2004), collaborative learning has five indispensable elements:

1. First, instructors should encourage positive interdependence in group work through the deliberate design of tasks. In this case, the goal of proposing original lesson plans strengthens positive interdependence, for all group members were jointly evaluated according to the success of their proposal. Sharing documents resources was a practical method for achieving this objective (each group had only one information package for the project in Seminar 2).

2. Second, instructors should arrange opportunities for face-to-face communication and mutual encouragement among members. In this case, different types of group work were combined throughout the process (Table 4).

3. Third, each member should be accountable for his or her contributions. In this case, to secure each student's personal ideas as a basis for group work, each student had to submit i) a personal report on their field work in the museum before they entered into group discussion of their findings and (ii) a personal exhibition proposal as a starting point for group work. To decrease "free riding", the instructor told the students that every member of the group must understand everything about their proposal, and this was checked by randomly selecting students and asking them questions in group interview sessions.

4. Fourth, social skills should be fostered. Basic skills of listening, accepting, and trust formation were taught through the peer interview sessions during the Teaching Profession course and through brainstorming in the Seminar 1. More complex skills pertaining to leadership, decision making, and conflict resolution were dealt with in the Seminars.

5. Fifth, instructors should provide opportunities for group members to reflect on each member's contribution. In this case, groups were required to record cooperative decision making during each step, including work conducted outside class hours. Each student had to 
write about every member's contribution (including their own) at the end of the Seminars 1 and 2.

\section{Examples of student-teacher interaction and cooperative learning}

In addition to designing the process of cooperative learning in advance, the author discovered ways in which instructors can challenge students especially when they are engaged in complex assignments such as the one in Seminar 2. For example, during an interview, one group presented a plan for a beautiful display of museum signage, created by a graphic design student. Two questions were raised. First, although the standard of visual presentation was excellent, it was the product of one member only and involved a very low level of cooperation. Second, beautiful signage does not necessarily facilitate active learning in viewers in an exhibition, because the work has already been completed by a professional. The direction of subsequent work was left to the discretion of the students. In the next group interview, they introduced a very different proposal. It was called "Four Seasons without Names", and was explained as follows:

Today, on account of our modern lifestyle, we have lost our natural sense of the transition of seasons...but we cannot return to the retrospective and stereotypical idea of Japan's traditional four seasons. ...Therefore, we propose the exhibition of an environment where visitors can experience their own sense of the seasons, namely, an experience of the seasons before they were named (Student booklet, 2003).

These students planned to exhibit Japanese art works conveying a sensory experience of the seasons, using tatami (straw mats) on the floor to convert the gallery space into a traditional interior space. They placed a Japanese-style garden at the side of the gallery to give the impression of a continuous stream of seasons. Visitors would be able to sit on the tatami mats and appreciate the pictures from a lower angle than is possible in a typical art gallery (Figure 1).

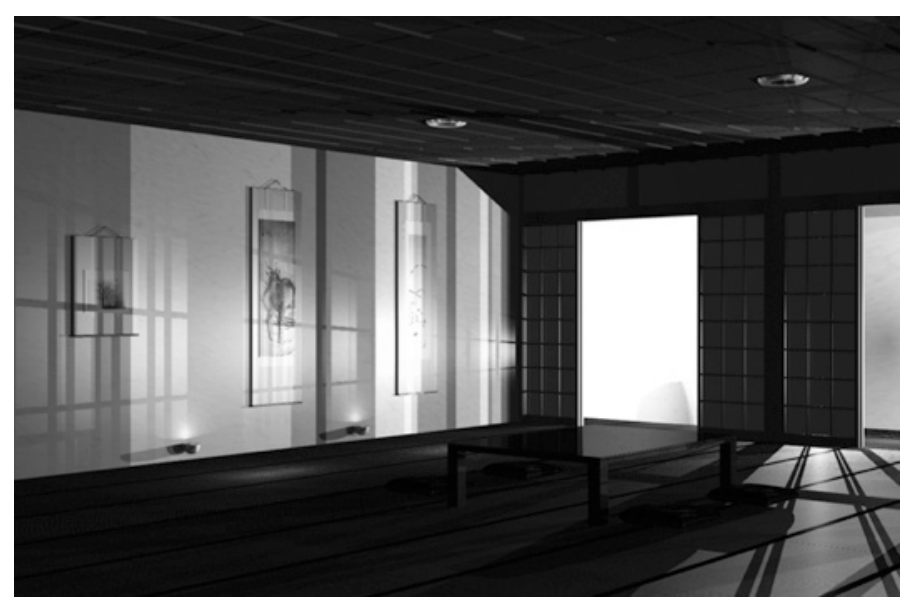

Figure 1: Gallery space with a transition of light 
The students also planned to recreate the natural transitions of light that occur during the seasons. They wanted the gallery space to be softly illuminated in the evenings by traditional lanterns (Figure 2).

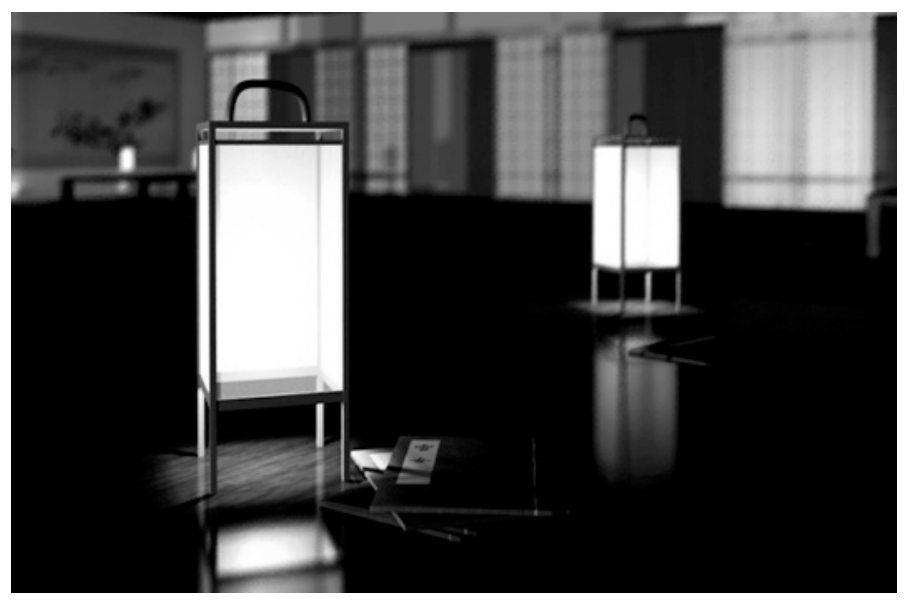

Figure 2: Traditional lanterns and handmade books.

They planned educational workshops also involving the creation of traditional-style books of folk tales evoking a sense of the seasons. The workshops were designed to afford visitors opportunities to speak with elderly people about their memories of seasons, and allow them to share personal experiences with people from different age groups in an artistic environment.

In the example described above, an art history student took a leadership role in writing and realising the main concept. Graphic design students took charge of editing the proposed booklet and the three-dimensional work was done on computer (see Figures 1 and 2). A calligraphy student was a principal contributor to the idea of creating traditional-style books.

This example illustrates positive student reactions to instructor intervention in a cooperative learning context. These students demonstrated an advanced level of understanding with respect to the given task of proposing a museum viewer-centred learning environment. They also demonstrated an advanced level of cooperation through role sharing and integration of shared work into a single concept.

The proposals generated by the other four groups in his class were diverse interpretations of the task. This was useful educationally because it facilitated understanding of multiple viewpoints. The following are short descriptions of each proposal: 


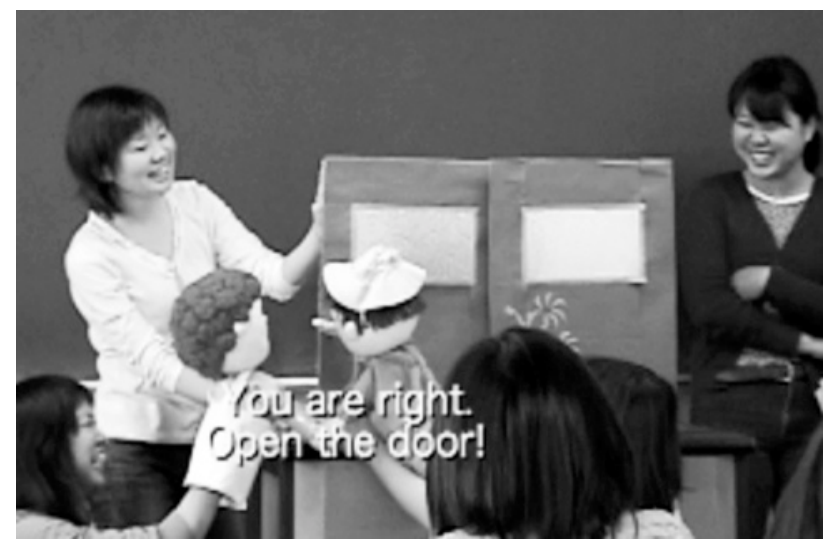

Figure 3: Open, See, Enter

“Open, See, Enter" (Figure 3).

This group conceptualised art as a door or window to another world. The students divided the gallery space into small rooms, each exhibiting a single work of art. When visitors opened the door they viewed décor and furniture designed to suit this particular artwork. The students communicated this proposal using a puppet theatre and miniature gallery in the final presentation to class members.

"Mere Art, but Art" This group proposed a series of communication games involving making and talking about works of art. There was active discussion with other groups about topics such as "How to organise learning activities that motivate children" with respect to this proposal.

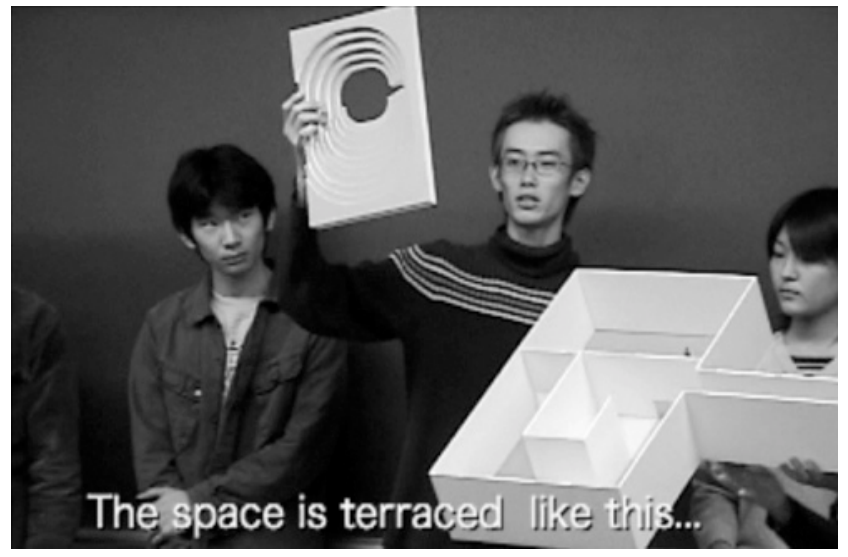

Figure 4: Significance of Seeing

"Significance of Seeing” (Figure 4). Using a small-scale model of a building, a student with a 
background in architectural design produced an original plan for renovating the gallery space into a terraced, inverted conical structure to house workshops involving observation and creation of art. Painting and sculpture students made sample work for the workshops. This project was successful in terms of achieving cooperation between students with different kinds of specialist training in fine art and design.

"Art nursery school"'. In this project the students proposed that the gallery be converted into a children's play garden; somewhere, for example, where children could attend a storytelling session about art works involving the use of illustrated picture cards. Their plan was to encourage children to make their own picture books based on experiences in the gallery. One point of discussion was how to maintain a balance between an environment that is both enjoyable and safe.

An anonymous survey at the end of the Comprehensive Seminar 2 (June 2003) indicated that almost seventy percent of respondents evaluated their engagement in this task as being either the highest level (33.3 per cent) or second-highest level (36.4 per cent) (See Table 5). The survey also indicated that almost eighty-five per cent of respondents rated their satisfaction with the class as either the highest level (45.5 per cent) or second-highest level (39.4 per cent, Table 6).

Anonymous survey: (33 of 34 students in class A responded)

\begin{tabular}{ccccccc}
\hline Level of engagement & 5. good & 4. & 3. moderate & 2. & 1. bad & total \\
\hline No of respondents & 11 & 12 & 7 & 3 & 0 & 33 \\
Percentages & 33.3 & 36.4 & 21.2 & 9.1 & 0.0 & 100.0 \\
\hline
\end{tabular}

\section{Table 5: Self-evaluation of engagement}

Anonymous survey: (33/ 34 students in class A responded)

\begin{tabular}{lllllll}
\hline Degree of satisfaction & 5. good & 4. & 3. moderate & 2. & 1. bad & total \\
\hline No of respondents & 15 & 13 & 4 & 1 & 0 & 33 \\
Percentages & 45.5 & 39.4 & 12.1 & 3.0 & 0.0 & 100.0 \\
\hline
\end{tabular}

\section{Table 6: Student satisfaction with course}

We have experienced more practical difficulties managing Comprehensive Seminar 2 than previous courses. In cooperative learning, instructors always have to supervise activities so as to diminish free-riding, especially when working in larger groups, and encourage students to reflect and appreciate the contributions of others (and so forth). In a few cases, the selection of group members may affect performance to an extent that problems occur that cannot be overcome. Using smaller groups can minimise this side effect. On the other hand, experiencing conflict while working in a large group can be a learning experience, from which lessons can be applied to real life situations. 


\section{Conclusion}

New courses based on cooperative learning were incorporated in the introductory stages of an art teacher-training programme at the University of Tsukuba in an effort to an increase the numbers of students who enrol on and completed it. This occurred despite the fact that the national teacher education system reforms have added to the study workload. The numbers of students who obtained teaching certificates in the School of Art and Design (annual admission 100 students) steadily increased from 28 in 2000 to 52 in 2004 - the year the first batch of students graduated from the new teacher education programme. Since 2004, around the same number of students have obtained certificates every year (Table 7).

\begin{tabular}{cccccccc}
\hline Year & 2000 & 2001 & 2002 & 2003 & 2004 & 2005 & 2006 \\
\hline No of students & 28 & 40 & 21 & 29 & 52 & 42 & 50 \\
\hline
\end{tabular}

Table 7: Students obtaining teaching certificates between 2000 and 2006

From the viewpoint of curriculum development, students attending courses based on principles of cooperative learning report a high degree of engagement and satisfaction. A gradual increase in human interaction through group work has resulted in learning that necessitates social skills. As indicated in the evaluation survey of art students, this challenges art students' tendencies towards individualism, and helps them to overcome feelings of inferiority associated with social communication.

Our experiments to date suggest that cooperative learning is effective in meeting professional objectives at the introductory stages of teacher education. At the University Tsukuba art students are provided with an orientation to teaching and reflect on the necessary competencies actively in an informal group setting in the course Teaching Profession. They acquire the social skills necessary for developing community-based educational projects when they engage in learning activities in formal groups in the Comprehensive Seminar. The teaching- learning methods outlined in this paper are relevant not only to Japanese teacher education, but have potential for training teachers in other countries where similar teacher competencies are considered indispensable.

\section{References}

「教育職員免許法」, 法律147号, 1949年, 改正2000年. [Teacher Licensing Act. (Act No.147, 1949, Amended in 2000, Japan)]

教員養成審議会第一次答申「新たな時代に向けた教員養成の改善方策について」1997年). [Advisory Panel on Teacher Education. (1997), On Policy for the Reform of the Teacher Education System for the New Generation: The First Report.] 
Feldman, E. (1970), Becoming Human through Art, Englewood Cliffs, NJ: Prentice-Hall, Inc. p. 358.

D.W.ジョンソン, R.T.ジョンソン, K.A.スミス, 関田一彦監訳『学生参加型の大学授業』玉 川大学出版部, 2001年. [Johnson, D.W., Johnson, R.T. \& Smith, K.A. (2001), Active Learning: Cooperating in the College Classroom (K. Sekita, Trans. into Japanese), Tokyo: Tamagawa University Press (Original work published in 1991).]

Mason, R. (1994), 'Artistic Achievement in Japanese Junior High Schools', Art Education, 47:1, pp. 8-19.

文部省令「大学設置基準」1956年, 改正2007年. [Ministry of Education, Culture, Sports, Science and Technology (1956, amended in 2007), University Establishment Standards. (Ministerial Ordinance, Japan)]

関田一彦「協同学習のすすめ」杉江、関田、安永、三宅『大学授業を活性化する方法』玉 川大学出版部, 2004年, pp.57-106. [Sekita, K. (2004), 'Introduction to Cooperative Learning'. In S. Sugie, K. Sugita, S. Yasunaga, \& N. Miyake (eds). Methods of Activating College Classes, Tokyo: Tamagawa University Press, pp. 57-106.]

塩田芳久『授業活性化のバズ学習入門』明治図書, 1989. [Shiota, Y. (1989), A Guide to 'Buzz Learning, for Class Activation, Tokyo: Meijitosho. ]

杉江修治「バズ学習の理論と実践」『数学教育』第43巻1号, 2001年, pp.83-90. [Sugie, S. (2001), 'Theory and Practice of Buzz Learning', Mathematics Education, 43:1, pp.83-90.]

杉江修治「協同学習による授業実践」『教育心理学年報』第43集，2004年，pp.156-165. [Sugie, S. (2004), 'Cooperative Learning and Improvement of School Learning', The Annual Report of Educational Psychology in Japan, 43, pp.156-165.]

高倉翔「教師とは何か」高倉, 加藤, 谷川『これからの教師』建帛社, 2000年, p.9. [Takakura, S. (2000). 'What is a Teacher', In S. Takakura., S. Kato \& A. Tanikawa (eds). New Teachers, Tokyo: Kenpakusha, p.9.]

安永悟，石川真人，満園良一「久留米大学における導入教育『共通演習』の成果と課題」 『京都大学高等教育研究』第12号，2006年，pp.15-25. [Yasukawa， S., Ishikawa， M. \& Mitsuzono, R. (2006), 'Outcomes and Issues of Freshman Seminars at Kurume University', Kyoto University Researches in Higher Education, 12, pp.15-25.]

\section{Contributor details}

NAOE Toshio, Ph.D., is Associate Professor at the Graduate School of Comprehensive Human Sciences, University of Tsukuba. He teaches art education in undergraduate, masters and doctorate programmes. Author of the Reform in Art Education in the First Half of the Twentieth Century in the United Kingdom. Japanese translator of Herbert Read's Education thorough Art.

Contact: University of Tsukuba, Institute of Art and Design, Tsukuba-shi, Ibaraki-ken, 305-8574 Japan.

naoe@geijutsu.tsukuba.ac.jp

http://www.geijutsu.tsukuba.ac.jp/ naoe/ 